\title{
Effect of stubble intercrop and biostimulants on the grain quality of spring wheat cultivated in monoculture
}

\author{
Wpływ międzyplonu ścierniskowego i biostymulatorów \\ na jakość ziarna pszenicy jarej uprawianej w monokulturze
}

\author{
Adela Maziarek $^{1 *}$, Danuta Parylak ${ }^{2}$, Roman Wacławowicz ${ }^{2}$
}

\section{Summary}

The field research was carried out at the Opole Agricultural Advisory Centre in Łosiów in 2011-2013. The aim of the study was to investigate cultivation of spring wheat crop in continuous cropping system, and to determine the effect of stubble intercrop and four different biostimulants on the quantity and quality of spring wheat grown in the short-term monoculture. The results showed that stubble intercrop cultivation with biostimulants application caused the increase of grain yield and improved its quality. Monoculture of spring wheat and the use of biostimulants decreased some quality parameters of grain.

Key words: spring wheat; monoculture; stubble crop; biostimulants; yield; quality parameters

\section{Streszczenie}

Badania polowe realizowano na terenie Opolskiego Ośrodka Doradztwa Rolniczego w Łosiowie w latach 2011-2013. Celem przeprowadzonych badań było poznanie reakcji pszenicy jarej na uprawę po sobie, a także określenie wpływu międzyplonu ścierniskowego i czterech różnych biostymulatorów na wielkość i jakość plonu pszenicy jarej uprawianej w krótkotrwałej monokulturze. $Z$ badanych czynników regeneracyjnych uprawa międzyplonu ścierniskowego i jednoczesne stosowanie biostymulatorów wpływało na wzrost plonu ziarna. Uprawa roślin w monokulturze oraz stosowanie biostymulatorów powodowało pogorszenie niektórych parametrów jakościowych ziarna.

Słowa kluczowe: pszenica jara; monokultura; międzyplon ścierniskowy; biostymulatory; plon; parametry jakościowe

\footnotetext{
Opolski Ośrodek Doradztwa Rolniczego w Łosiowie

Główna 1, 49-330 Łosiów

${ }^{2}$ Uniwersytet Przyrodniczy we Wrocławiu

PI. Grunwaldzki 24A, 50-363 Wrocław

*corresponding author: adela.maziarek@oodr.pl
} 


\section{Wstęp / Introduction}

W kształtowaniu większości cech jakościowych ziarna istotne znaczenie mają właściwości genetyczne, warunki atmosferyczne i siedliskowe oraz zabiegi agrotechniczne (Parylak 1999; Borkowska i wsp. 2002; Szwed-Urbaś i Segit 2004; Woźniak 2005). Na jakość ziarna pszenicy wpływa również przedplon oraz jego udział w zmianowaniu (Gontarz 2006; Woźniak 2007). Duży udział zbóż w strukturze zasiewów w Polsce wymusza ich wysiew bezpośrednio po sobie, a często nawet ich uprawę w monokulturze. Konsekwencją takich uproszczeń w zmianowaniu, oprócz obniżki plonu rośliny uprawnej, jest również pogorszenie jego parametrów jakościowych (Woźniak i Gontarz 2003; Woźniak 2004). Jest to szczególnie istotne w przypadku form, które niżej plonują np. pszenica jara (Cygankiewicz 1997). Woźniak i Staniszewski (2007) stwierdzili istotne zmniejszenie plonu oraz pogorszenie parametrów jakościowych ziarna pszenicy jarej uprawianej w monokulturze niż w zmianowaniach z 25-75\% jej udziałem w strukturze zasiewów.

Jednym ze sposobów łagodzenia ujemnych skutków uproszczeń $\mathrm{w}$ zmianowaniu jest uprawa międzyplonów ścierniskowych, które przyczyniają się do tworzenia trwałej materii organicznej oraz ograniczają wymywanie składników pokarmowych, stymulują aktywność biologiczną gleby i wpływają na ochronę jej potencjału produkcyjnego (Parylak 1999; Holland 2004; Dzienia i wsp. 2006; Kwiatkowski 2012). Międzyplony zwiększają także zasobność gleby w składniki pokarmowe, wpływając tym samym na wysokość i jakość plonu roślin następczych (Małecka i wsp. 2004; Weber 2010). Kwiatkowski i Misztal-Majewska (2014) zaobserwowali poprawę jakości ziarna pszenicy jarej w stanowiskach po różnych międzyplonach ścierniskowych.

W ostatnich latach obserwuje się tendencję do stosowania biopreparatów, które poprzez naturalną modyfikację metabolizmu roślin mogą wpływać na zwiększenie plonowania oraz poprawę parametrów jakościowych ziarna. Czeczko i Mikos-Bielak (2004) oraz Gawrońska i wsp. (2008) twierdzą, że stosowanie biostymulatora Asahi SL przyczynia się do wzrostu plonów oraz poprawy wybranych cech jakościowych i ilościowych ziarna pszenicy jarej, jednak wpływ preparatu jest zależny od fazy rozwojowej rośliny uprawnej oraz zmiennych w latach badań (Matysiak i wsp. 2011).

Celem badań było poznanie reakcji pszenicy jarej na uprawę w monokulturze, a także określenie wpływu zabiegów regeneracyjnych na plonowanie i jakość ziarna pszenicy uprawianej w trzyletniej monokulturze. Hipoteza badawcza zakładała korzystny wpływ zabiegów proekologicznych na plonowanie i wybrane parametry technologiczne ziarna.

\section{Materiały i metody / Materials and methods}

Badania przeprowadzono na terenie Opolskiego Ośrodka Doradztwa Rolniczego w Łosiowie w latach 2011-2013. Dwa ścisłe doświadczenia polowe zostały założone metodą losowanych podbloków, w czterech powtórzeniach na poletkach o wielkości $20 \mathrm{~m}^{2}$ zlokalizowanych na glebie brunatnej właściwej kompleksu pszennego dobrego o $\mathrm{pH}_{\mathrm{KCl}}=6,7$.

W doświadczeniu jednoczynnikowym badano wpływ następstwa roślin (płodozmian: rzepak ozimy - pszenica jara - jęczmień ozimy oraz monokultura pszenicy jarej) na plonowanie i jakość technologiczną ziarna pszenicy. W doświadczeniu dwuczynnikowym określono wpływ czterech biostymulatorów: Nano-Gro, Asahi SL, PRP EBV, Wuxal Ascofol i przyorywanego corocznie międzyplonu ścierniskowego z facelii błękitnej na plon i jakość ziarna pszenicy uprawianej bezpośrednio po sobie.

Biostymulatory zastosowano $\mathrm{w}$ postaci opryskiwania: Nano-Gro w fazie krzewienia i strzelania w źdźbło w dawce 5-8 granulek/200 1 wody/ha; Asahi SL w fazie krzewienia i fazie liścia flagowego - w dawce 0,6 1/ha; PRP EBV w fazie krzewienia - w dawce 2 1/ha; Wuxal Ascofol w fazie krzewienia i fazie liścia flagowego w dawce 2-3 1/ha.

Międzyplon ścierniskowy był wysiewany w sierpniu w ilości $14 \mathrm{~kg} / \mathrm{ha}$ i przyorywany jesienią (listopad) orką przedzimową.

Pszenicę jarą odmiany Monsun wysiewano w ilości $400 \mathrm{szt} . / \mathrm{m}^{2}$ siewnikiem rzędowym, w rozstawie $12,5 \mathrm{~cm}$. Przed siewem ziarno pszenicy zaprawiano preparatem Scenic 080 FS.

Nawożenie mineralne pod pszenicę jarą zastosowano w ilości $120 \mathrm{~kg} \mathrm{~N}$ w pierwszym i trzecim roku badań i $80 \mathrm{~kg} \mathrm{~N}$ w drugim roku. Ze względu na wysoką zasobność gleby w fosfor i potas nie stosowano nawożenia tymi składnikami.

W celu ochrony roślin przed zachwaszczeniem zastosowano herbicydy w fazie 2-3 liści pszenicy (BBCH 12-13). W pierwszym roku badań stosowano Granstar 75 WG (tribenuron metylowy) + Starane 250 EC (fluroksypyr) w dawce $15 \mathrm{~g}+0,3 \mathrm{l}$; w drugim i trzecim roku Granstar Ultra SX 50 SG (tribenuron metylowy + tifensulfuron metylowy) $\mathrm{z}$ adiuwantem Trend 90 EC (etoksylowany alkohol inadocylowy) w ilości $48 \mathrm{~g}+0,05 \%$. Występujące choroby grzybowe zwalczano preparatami: Capalo 337,5 EC (fenpropimorf + metrafenon + epoksykonazol) w ilości 1,5 1/ha w roku 2011, Input 460 EC (spiroksamina + protiokonazol) + Fandango 200 EC (protiokonazol + fluoksastrobina) w dawkach 0,5 1/ha w 2012 roku oraz Aviator XPro 250 EC (protiokonazol + biksafen) w dawce 1 1/ha i Menara 410 EC (propikonazol + cyprokonazol) w dawce 0,5 1/ha w 2013 roku. Na szkodniki w drugim i trzecim roku badań zastosowano środek Karate Zeon 050 SC (lambda-cyhalotryna) w ilości 0,12 1/ha. Środki ochrony roślin aplikowano przy użyciu opryskiwacza polowego Pilmet o ciśnieniu 0,35 MPa i wydatku cieczy roboczej 200 1/ha.

Zbiór pszenicy jarej przeprowadzono w fazie dojrzałości pełnej, a następnie określono plon ziarna o wilgotności $15 \%$. Przedstawione w pracy cechy jakościowe ziarna oznaczono w laboratorium Opolskiego Ośrodka Doradztwa Rolniczego zgodnie $\mathrm{z}$ odpowiednimi normami: zawartość białka ogólnego (PN 75/A-04018), ilość glutenu (PN 77/A-74041), gęstość ziarna (PN-ISO 9771-2), liczba sedymentacji (PN-ISO 5529), liczba opadania (PN-ISO 3093). 
Tabela 1. Temperatura powietrza i opady w okresie wegetacji pszenicy jarej (2011-2013)

Table 1. Air temperature and precipitation during the growing season of spring wheat (2011-2013)

\begin{tabular}{c|c|c|c|c|c|c|c|c}
\hline \multirow{2}{*}{$\begin{array}{c}\text { Miesiąc } \\
\text { Month }\end{array}$} & \multicolumn{4}{|c|}{ Temperatura - Temperature $\left[{ }^{\circ} \mathrm{C}\right]$} & \multicolumn{4}{c}{ Opady-Rainfall [mm] } \\
\cline { 2 - 10 } & 2011 & 2012 & 2013 & $1976-2010$ & 2011 & 2012 & 2013 & $1976-2010$ \\
\hline IV & 11,5 & 9,0 & 8,3 & 8,5 & 29,1 & 26,3 & 37,4 & 39,1 \\
\hline V & 14,8 & 15,3 & 14,2 & 14,2 & 45,3 & 45,4 & 107,4 & 57,6 \\
\hline VI & 19,2 & 17,2 & 17,6 & 17,1 & 118,3 & 107,6 & 148,9 & 78,9 \\
\hline VII & 18,0 & 20,2 & 20,7 & 18,9 & 154,1 & 71,7 & 30,1 & 96,0 \\
\hline VIII & 19,6 & 19,1 & 19,8 & 18,5 & 79,8 & 76,4 & 37,1 & 71,4 \\
\hline
\end{tabular}

Ocenę warunków pogodowych przeprowadzono na podstawie danych z Punktu Meteorologicznego Opolskiego Ośrodka Doradztwa Rolniczego w Łosiowie (tab. 1). W okresie prowadzenia badań średnie temperatury powietrza we wszystkich latach były wyższe niż przeciętne. W pierwszym roku szczególnie wysokie temperatury $\mathrm{w}$ stosunku do wielolecia odnotowano w kwietniu i czerwcu. Lata badań różniły się także rozkładem opadów. Suma opadów w roku 2011 znacznie (o 83,6 mm) przewyższała średnie wartości w rejonie, a największe opady odnotowano $\mathrm{w}$ lipcu. W pierwszym roku badań niekorzystnie na rozwój pszenicy jarej wpłynęły obfite opady śniegu w dniu 3 maja oraz przymrozki, które wystąpiły od 4 do 6 maja. Suma opadów w roku 2012 była nieznacznie mniejsza niż w wieloleciu. Również w trzecim roku badań rozkład opadów w okresie od maja do sierpnia znacznie odbiegał od średnich wieloletnich. Najwięcej deszczu spadło w maju i czerwcu, natomiast w okresie dojrzewania ziarna wystąpiły niedobory wody. Ponadto okres wegetacji pszenicy jarej w ostatnim roku badań uległ skróceniu ze względu na przedłużającą się zimę, a opóźnienie siewów o ponad dwa tygodnie odbiło się na kondycji roślin.

Wyniki trzyletnich badań poddano analizie wariancji, a istotność różnic między średnimi oceniano testem t-Studenta na poziomie $\alpha=0,05$.

\section{Wyniki i dyskusja / Results and discussion}

W badaniach nie stwierdzono istotnego wpływu następstwa roślin na plonowanie pszenicy jarej, chociaż uprawa pszenicy po sobie obniżyła plon ziarna o 0,79 t/ha w porównaniu z uprawą w płodozmianie (rys. 1). Woźniak (2003, 2006) donosi, że uprawa w monokulturze redukuje plon ziarna pszenicy jarej o ponad 36\%, a pszenicy ozimej o około $20 \% \mathrm{w}$ stosunku do zmianowania. Także badania Gontarza (2006) wykazały mniejsze o 20-24\% plony pszenicy twardej wysiewanej bezpośrednio po sobie w porównaniu do uprawy po dobrych przedplonach (groch i ziemniaki). Niekorzystną reakcję zbóż na uprawę po sobie potwierdzają także Kotwica i wsp. (2013), którzy obserwowali 17\% obniżkę plonu ziarna pszenicy ozimej uprawianej w krótkotrwałej monokulturze. Przeprowadzone badania wykazały istotny wpływ stanowiska na większość parametrów technologicznych ziarna (tab. 2). Uprawa pszenicy jarej bezpośrednio po sobie zmniejszała zawartość białka ogólnego o 0,86 pkt. \%, ilość glutenu o 3 pkt. \% oraz gęstość w stanie zsypnym o $1,6 \%$ w stosunku do uprawy w płodozmianie. Także w badaniach Woźniaka (2004) pszenica jara w monokulturze odznaczała się znacznie niższą wartością technologiczną ziarna $\mathrm{w}$ porównaniu $\mathrm{z}$ jej uprawą po dobrych przedplonach. Kilkakrotny wysiew pszenicy jarej po sobie wpływa na zmniejszenie zawartości białka ogólnego i glutenu w ziarnie, a także wartości wskaźnika sedymentacji Zeleny'ego, gęstości i wyrównania ziarna w stosunku do uprawy w zmianowaniu (Woźniak 2003).

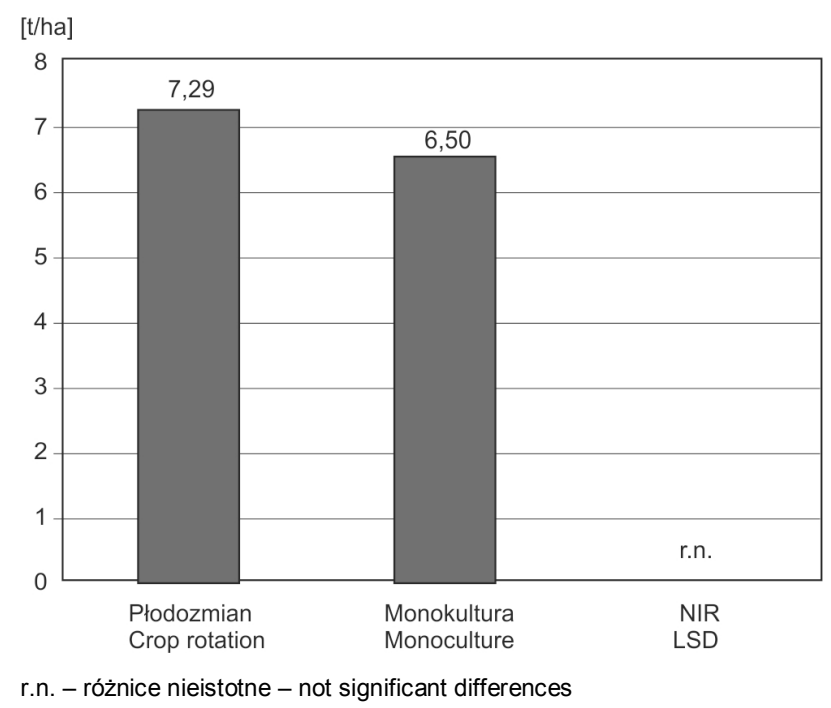

Rys. 1. Wpływ następstwa roślin na plonowanie pszenicy jarej Fig. 1. Effect of crop succession on the yield of spring wheat

Coroczne przyorywanie międzyplonu ścierniskowego powodowało istotny $3,1 \%$ wzrost plonu ziarna pszenicy jarej uprawianej w monokulturze (tab. 3). Podobnie w badaniach Gawędy i Kwiatkowskiego (2012) przyoranie międzyplonu $\mathrm{z}$ facelii błękitnej w monokulturze pszenicy jarej zwiększało plon ziarna o 3,3\% w porównaniu do poletek bez międzyplonu. W opinii Harasim i Gawędy (2010) wprowadzenie w monokulturze pszenicy jarej międzyplonu ścierniskowego zwiększa plon ziarna tego zboża o $9,4 \%$.

Uprawa międzyplonu ścierniskowego, jako ,przerywnika" fitosanitarnego w monokulturze przyczyniła się do poprawy parametrów jakościowych ziarna w stosunku do ziarna pszenicy uprawianej bezpośrednio po sobie (tab. 4, 5). W stanowisku po międzyplonie stwierdzono wyższą zawartość białka i glutenu (o 0,16 pkt. \% i 0,6 pkt. \%). 
Tabela 2. Wpływ następstwa roślin na jakość ziarna pszenicy jarej

Table 2. Effect of crop succession on grain quality of spring wheat

\begin{tabular}{l|c|c|c|c|c}
\hline $\begin{array}{c}\text { Następstwo roślin } \\
\text { Plant succession }\end{array}$ & $\begin{array}{c}\text { Zawartość białka } \\
\text { Protein content } \\
{[\% \text { s.m. }]}\end{array}$ & $\begin{array}{c}\text { Ilość glutenu } \\
\text { Gluten } \\
{[\%]}\end{array}$ & $\begin{array}{c}\text { Wskaźnik } \\
\text { sedymentacyjny } \\
\text { Zelenyego } \\
\text { Zeleny sedimentation } \\
\text { rate }\end{array}$ & $\begin{array}{c}\text { Liczba } \\
\text { opadania } \\
\text { Falling number } \\
{[\mathrm{s}]}\end{array}$ & $\begin{array}{c}\text { Ciężar hektolitra ziarna } \\
\text { Bulk density of grain } \\
{[\mathrm{kg} / \mathrm{hl}]}\end{array}$ \\
\hline Płodozmian - Crop rotation & 12,47 & 25,2 & 45 & 404 & 76,99 \\
\hline Monokultura - Monoculture & 11,61 & 22,2 & 44 & 402 & 75,78 \\
\hline NIR (0,05) - LSD $(0.05)$ & 0,06 & 0,5 & r.n. & r.n. & 0,17 \\
\hline
\end{tabular}

r.n. - różnice nieistotne - not significant differences

Tabela 3. Wpływ międzyplonu i biostymulatorów na plonowanie pszenicy jarej uprawianej w monokulturze

Table 3. The effect of stubble crop and biostimulants on yield of spring wheat cultivated in monoculture

\begin{tabular}{|c|c|c|c|}
\hline \multirow{3}{*}{$\begin{array}{l}\text { Biostymulator } \\
\text { Biostimulant }\end{array}$} & \multicolumn{2}{|c|}{ Monokultura - Monoculture } & \multirow{2}{*}{$\begin{array}{c}\text { Średnio } \\
\text { Mean }\end{array}$} \\
\hline & $\begin{array}{l}\text { bez międzyplonu } \\
\text { without stubble crop }\end{array}$ & $\begin{array}{l}\text { z międzyplonem } \\
\text { with stubble crop }\end{array}$ & \\
\hline & \multicolumn{3}{|c|}{$[\mathrm{t} / \mathrm{ha}]$} \\
\hline Brak - Without & 6,50 & 6,33 & 6,42 \\
\hline Nano-Gro & 6,44 & 6,65 & 6,54 \\
\hline Asahi SL & 6,60 & 7,08 & 6,84 \\
\hline PRP EBV & 6,31 & 6,59 & 6,45 \\
\hline Wuxal Ascofol & 6,70 & 6,90 & 6,80 \\
\hline Średnio - Mean & 6,51 & 6,71 & - \\
\hline NIR $(0,05)$ dla międzyplonu - LSD $(0.05)$ for stubble crop & \multicolumn{3}{|c|}{0,18} \\
\hline NIR $(0,05)$ dla biostymulatora - LSD $(0.05)$ for biostymulant & \multicolumn{3}{|c|}{ r.n. } \\
\hline NIR $(0,05)$ dla interakcji - LSD $(0.05)$ for interaction & \multicolumn{3}{|c|}{ r.n. } \\
\hline
\end{tabular}

r.n. - różnice nieistotne - not significant differences

Tabela 4. Zawartość białka i glutenu w zależności od zastosowanych zabiegów regeneracyjnych

Table 4. The content of protein and gluten depending upon the regenerative treatments

\begin{tabular}{|c|c|c|c|c|c|c|}
\hline \multirow{4}{*}{$\begin{array}{l}\text { Biostymulator } \\
\text { Biostymulant }\end{array}$} & \multicolumn{3}{|c|}{ Zawartość białka - Protein content } & \multicolumn{3}{|c|}{ Ilość glutenu - Gluten content } \\
\hline & \multicolumn{2}{|c|}{ monokultura - monoculture } & \multirow[b]{2}{*}{$\begin{array}{c}\text { średnio } \\
\text { mean }\end{array}$} & \multicolumn{2}{|c|}{ monokultura - monoculture } & \multirow[b]{2}{*}{$\begin{array}{c}\text { średnio } \\
\text { mean }\end{array}$} \\
\hline & $\begin{array}{l}\text { bez międzyplonu } \\
\text { without stubble crop }\end{array}$ & $\begin{array}{l}\mathrm{z} \text { międzyplonem } \\
\text { with stubble crop }\end{array}$ & & $\begin{array}{c}\text { bez międzyplonu } \\
\text { without stubble crop }\end{array}$ & $\begin{array}{l}\mathrm{z} \text { międzyplonem } \\
\text { with stubble crop }\end{array}$ & \\
\hline & \multicolumn{3}{|c|}{ [\% s.m. $]$} & \multicolumn{3}{|c|}{$[\%]$} \\
\hline Brak - Without & 11,61 & 11,86 & 11,74 & 22,1 & 22,0 & 22,1 \\
\hline Nano-Gro & 11,23 & 11,40 & 11,32 & 21,2 & 22,3 & 21,8 \\
\hline Asahi SL & 11,32 & 11,53 & 11,42 & 21,7 & 22,2 & 21,9 \\
\hline PRP EBV & 11,52 & 11,73 & 11,63 & 21,4 & 21,8 & 21,6 \\
\hline Wuxal Ascofol & 11,40 & 11,39 & 11,39 & 21,1 & 22,0 & 21,6 \\
\hline Średnio - Mean & 11,42 & 11,58 & - & 21,5 & 22,1 & - \\
\hline $\begin{array}{l}\text { NIR }(0,05) \text { dla międzyplonu } \\
\text { LSD }(0.05) \text { for stubble crop }\end{array}$ & \multicolumn{3}{|c|}{0,02} & \multicolumn{3}{|c|}{0,2} \\
\hline $\begin{array}{l}\text { NIR }(0,05) \text { dla } \\
\text { biostymulatora } \\
\text { LSD }(0.05) \text { for biostymulant }\end{array}$ & \multicolumn{3}{|c|}{0,03} & \multicolumn{3}{|c|}{0,2} \\
\hline $\begin{array}{l}\text { NIR }(0,05) \text { dla interakcji } \\
\operatorname{LSD}(0.05) \text { for interaction }\end{array}$ & \multicolumn{3}{|c|}{0,04} & \multicolumn{3}{|c|}{0,3} \\
\hline
\end{tabular}

r.n. - różnice nieistotne - not significant differences 
Tabela 5. Wyróżniki jakości ziarna w zależności od zastosowanych zabiegów regeneracyjnych

Table 5. Highlights of grain quality depending on the applied regeneration treatments

\begin{tabular}{|c|c|c|c|c|c|c|c|c|c|}
\hline \multirow{4}{*}{$\begin{array}{l}\text { Biostymulator } \\
\text { Biostymulant }\end{array}$} & \multicolumn{3}{|c|}{$\begin{array}{c}\text { Wskaźnik sedymentacyjny Zelenyego } \\
\text { Zeleny sedimentation rate }\end{array}$} & \multicolumn{3}{|c|}{$\begin{array}{l}\text { Liczba opadania } \\
\text { Falling number }\end{array}$} & \multicolumn{3}{|c|}{$\begin{array}{l}\text { Ciężar hektolitra ziarna } \\
\text { Bulk density of grain }\end{array}$} \\
\hline & \multicolumn{2}{|c|}{ monokultura - monoculture } & \multirow[b]{2}{*}{$\begin{array}{l}\text { średnio } \\
\text { mean }\end{array}$} & \multicolumn{2}{|c|}{ monokultura - monoculture } & \multirow[b]{2}{*}{$\begin{array}{l}\text { średnio } \\
\text { mean }\end{array}$} & \multicolumn{2}{|c|}{ monokultura - monoculture } & \multirow[b]{2}{*}{$\begin{array}{c}\text { średnio } \\
\text { mean }\end{array}$} \\
\hline & $\begin{array}{l}\text { bez między- } \\
\text { plonu } \\
\text { without } \\
\text { stubble crop }\end{array}$ & $\begin{array}{l}\text { z między- } \\
\text { plonem } \\
\text { with } \\
\text { stubble crop }\end{array}$ & & $\begin{array}{c}\text { bez między- } \\
\text { plonu } \\
\text { without } \\
\text { stubble crop }\end{array}$ & $\begin{array}{l}\text { z między- } \\
\text { plonem } \\
\text { with } \\
\text { stubble crop }\end{array}$ & & $\begin{array}{c}\text { bez między- } \\
\text { plonu } \\
\text { without } \\
\text { stubble crop }\end{array}$ & $\begin{array}{l}\text { z między- } \\
\text { plonem } \\
\text { with } \\
\text { stubble crop }\end{array}$ & \\
\hline & & & & \multicolumn{3}{|c|}{$[\mathrm{s}]$} & \multicolumn{3}{|c|}{$[\mathrm{kg} / \mathrm{hl}]$} \\
\hline $\begin{array}{l}\text { Brak } \\
\text { Without }\end{array}$ & 44 & 46 & 45 & 403 & 405 & 404 & 75,78 & 75,92 & 75,85 \\
\hline Nano-Gro & 41 & 46 & 43 & 394 & 407 & 401 & 75,73 & 76,23 & 75,98 \\
\hline Asahi SL & 41 & 43 & 42 & 405 & 407 & 406 & 75,23 & 75,72 & 75,46 \\
\hline PRP EBV & 44 & 46 & 45 & 403 & 421 & 412 & 75,43 & 75,43 & 75,43 \\
\hline Wuxal Ascofol & 43 & 45 & 44 & 412 & 401 & 407 & 75,32 & 75,92 & 75,62 \\
\hline $\begin{array}{l}\text { Średnio } \\
\text { Mean }\end{array}$ & 43 & 45 & - & 403 & 408 & - & 75,50 & 75,85 & - \\
\hline $\begin{array}{l}\text { NIR }(0,05) \text { dla } \\
\text { międzyplonu } \\
\text { LSD }(0.05) \text { for } \\
\text { stubble crop }\end{array}$ & \multicolumn{3}{|c|}{2} & \multicolumn{3}{|c|}{2} & \multicolumn{3}{|c|}{0,01} \\
\hline $\begin{array}{l}\text { NIR }(0,05) \text { dla } \\
\text { biostymulatora } \\
\text { LSD }(0.05) \text { for } \\
\text { biostymulant }\end{array}$ & \multicolumn{3}{|c|}{1} & \multicolumn{3}{|c|}{2} & \multicolumn{3}{|c|}{0,02} \\
\hline $\begin{array}{l}\text { NIR }(0,05) \text { dla } \\
\text { interakcji } \\
\text { LSD }(0.05) \text { for } \\
\text { interaction }\end{array}$ & \multicolumn{3}{|c|}{ r.n. } & \multicolumn{3}{|c|}{3} & \multicolumn{3}{|c|}{0,02} \\
\hline
\end{tabular}

r.n. - różnice nieistotne - not significant differences

Także wskaźnik sedymentacji, liczba opadania oraz gęstość ziarna były wyższe niż w stanowisku bez międzyplonu odpowiednio o 4,7\%, 1,2\% i $0,5 \%$. W badaniach Kwiatkowskiego i Misztal-Majewskiej (2014) wszystkie użyte w doświadczeniu międzyplony ścierniskowe wpływały na poprawę jakości ziarna pszenicy jarej uprawianej w monokulturze. Kraska (2010) stwierdził największą zawartość białka w ziarnie pszenicy jarej w stanowiskach z wsiewką koniczyny czerwonej i życicy westerwoldzkiej oraz poplonem facelii błękitnej, a liczbę opadania i indeks glutenu w ziarnie pszenicy jarej z koniczyną czerwona w porównaniu do poletek kontrolnych. Z kolei Wacławowicz i wsp. (2005) nie zaobserwowali wyraźnych zmian w zawartości białka ogólnego w ziarnie pszenicy jarej pod wpływem stosowania pod przedplon międzyplonu ścierniskowego. Podobnie Tendziagolska i Parylak (2004) nie wykazały jednoznacznego wpływu międzyplonu z gorczycy białej na zawartość białka ogólnego w pszenżycie ozimym uprawianym w monokulturze. Gil i wsp. (2008) stwierdzili natomiast, że efektem następczym przyorywania międzyplonu ścierniskowego pod pszenicę jarą jest obniżenie zawartości białka ogólnego w ziarnie.

Plonowanie pszenicy jarej nie zależało od stosowanych w monokulturze biostymulatorów, stwierdzono natomiast ich znaczny wpływ na jakość ziarna pszenicy jarej.
Zarówno zawartość białka, jak i ilość glutenu były istotnie mniejsze po aplikacji preparatów biostymulujących niż w ziarnie pszenicy, w której nie stosowano biostymulatorów (tab. 4). Najmniej korzystny wpływ na zawartość białka miał preparat Nano-Gro, a na zawartość glutenu PRP EBV i Wuxal Ascofol. Także wskaźnik sedymentacji na obecność biostymulatorów reagował na ogół obniżką, a najniższą wartość tego parametru odnotowano po użyciu Asahi SL (o 6,7\%). Jednakże stwierdzono również korzystne oddziaływanie biopreparatów na niektóre cechy ziarna (tab. 5). Po użyciu preparatów PRP EBV, Wuxal Ascofol i Asahi SL obserwowano wzrost liczby opadania w stosunku do pszenicy nietraktowanej środkami biostymulującymi, odpowiednio o 2,0\%, 0,7\% i 0,5\%. Z kolei gęstość ziarna zwiększyła się jedynie po aplikacji Nano-Gro $(0,2 \%)$, a pozostałe preparaty obniżały jej wartość średnio o $0,5 \%$. Białkowska i Wójtowicz (2011) testując preparat Sunagreen nie stwierdziły jego wpływu na zawartość białka i thuszczu surowego w ziarnie jęczmienia jarego. Kołodziejczyk i wsp. (2012) wykazali, że preparaty mikrobiologiczne: Proplant AM, Efektywne Mikroorganizmy EM oraz UGmax w niewielkim stopniu oddziaływały na jakość ziarna pszenicy jarej, a ich korzystny wpływ odnotowano tylko na parametr gęstości ziarna po zastosowaniu preparatu EM. 
W badaniach własnych stwierdzono interakcję pomiędzy uprawą międzyplonu a stosowaniem biostymulatorów w odniesieniu do większości parametrów jakościowych ziarna pszenicy jarej (tab. 4, 5). Zawartość białka, ilość glutenu oraz gęstość ziarna były istotnie większe na poletkach, gdzie nie stosowano międzyplonu i biostymulatorów. W warunkach corocznego przyorywania facelii błękitnej zawartość białka i gęstość ziarna najkorzystniej kształtowały się na poletkach, gdzie nie stosowano biostymulatorów. Zwiększenie gęstości ziarna obserwowano także po aplikacji preparatu Wuxal Ascofol. W stanowisku z przyoranym międzyplonem tylko użycie biostymulatora Nano-Gro sprzyjało zwiększeniu ilości glutenu w ziarnie. Największy wzrost liczby opadania obserwowano po zastosowaniu środka Wuxal Ascofol w warunkach braku międzyplonu ścierniskowego oraz po Nano-Gro, jeżeli międzyplon był przyorywany.

\section{Wnioski / Conclusions}

1. Uprawa pszenicy jarej w krótkotrwałej monokulturze, $\mathrm{w}$ porównaniu $\mathrm{z}$ uprawą $\mathrm{w}$ płodozmianie rzepak ozimy
- pszenica jara - jęczmień ozimy, nie wpływała istotnie na plonowanie, natomiast spowodowała pogorszenie jakości ziarna.

2. W monokulturze pszenicy jarej coroczne przyorywanie międzyplonu ścierniskowego $\mathrm{z}$ facelii błękitnej $\mathrm{w}$ niewielkim stopniu wpływało na wzrost plonu oraz na ogół poprawiało parametry jakościowe ziarna.

3. Nie stwierdzono istotnego wpływu biostymulatorów na plonowanie pszenicy jarej. Ich stosowanie powodowało natomiast istotne obniżenie większości parametrów jakościowych ziarna $\mathrm{w}$ porównaniu z pszenicą, której nie traktowano biostymulatorami. Jedynie po aplikacji preparatów PRP EBV, Wuxal Ascofol i Asahi SL obserwowano istotne zwiększenie liczby opadania, a po Nano-Gro gęstości w stanie zsypnym.

4. Łączne stosowanie międzyplonu ścierniskowego i biostymulatorów w monokulturze pszenicy jarej w porównaniu do pszenicy w agrotechnice której nie stosowano żadnych zabiegów regeneracyjnych, wpływało istotnie na parametry jakościowe ziarna, choć kierunek zmian był niejednoznaczny.

\section{Literatura / References}

Białkowska M., Wójtowicz A. 2011. Reakcja jęczmienia browarnego na aplikację biostymulatora Sunagreen. Episteme 12 (1): $133-141$.

Borkowska H., Grundas S., Styk B. 2002. Wysokość i jakość plonów niektórych odmian pszenicy jarej w zależności od nawożenia azotowego. Annales Universitatis Mariae Curie-Skłodowska, Sectio E, Agricultura 57: 99-103.

Cygankiewicz A. 1997. Wartość technologiczna ziarna materiałów hodowlanych pszenicy ozimej i jarej na tle badań własnych i światowych. Biuletyn Instytutu Hodowli i Aklimatyzacji Roślin 204: 219-235.

Czeczko R., Mikos-Bielak M. 2004. Effects of Asahi bio-stimulator application in the cultivation of different vegetable species. Annales Universitatis Mariae Curie-Skłodowska, Sectio E, Agricultura 59 (3): 1073-1079.

Dzienia S., Zimny L., Weber R. 2006. Najnowsze kierunki w uprawie roli i technice siewu. Fragmenta Agronomica 2: $227-241$.

Gawęda D., Kwiatkowski C. 2012. Plonowanie pszenicy jarej uprawianej w krótkotrwałej monokulturze w zależności od międzyplonu i sposobu odchwaszczania. Annales Universitatis Mariae Curie-Skłodowska, Sectio E, Agricultura 67 (2): 50-58.

Gawrońska H., Przybysz A., Szalacha E., Słowiński A. 2008. Physiological and molecular mode of action of Asahi SL biostymulator under optimal and stress conditions. p. 54-77. In: "Biostimulators in Modern Agriculture. General Aspects" (H. Gawrońska, ed.). Editorial House Wieś Jutra, Warsaw, 89 pp.

Gil Z., Narkiewicz-Jodko M., Wojciechowski W., Spychaj R. 2008. Wpływ międzyplonu i nawożenia azotem na wartość technologiczną ziarna pszenicy jarej. Fragmenta Agronomica 25, 1 (97): 134-144.

Gontarz D. 2006. Plonowanie i jakość technologiczna ziarna pszenicy zwyczajnej (Triticum aestivum L.) i pszenicy twardej (Triticum durum Desf.) w zależności od przedplonu i poziomu agrotechniki. Rozprawa doktorska. Akademia Rolnicza w Lublinie, 95 ss.

Harasim E., Gawęda D. 2010. Wpływ międzyplonów ścierniskowych na plonowanie i efektywność energetyczną produkcji zbóż jarych. Annales Universitatis Mariae Curie-Skłodowska, Sectio E, Agricultura 65 (1): 64-72.

Holland J.M. 2004. The environmental consequences of adopting conservation tillage in Europe: reviewing the evidence. Agriculture, Ecosystems \& Environment 103: 1-25.

Kołodziejczyk M., Szmigiel A., Oleksy A. 2012. Wpływ nawożenia azotem oraz mikrobiologicznych preparatów poprawiających właściwości gleby na zawartość białka i wybrane cechy fizyczne ziarna pszenicy jarej. Fragmenta Agronomica 29 (2): 68-76.

Kotwica K., Jaskulska I., Piekarczyk M., Wasilewski P., Gałęzewski L., Kulpa D. 2013. Wpływ użyźniania gleby oraz stosowania biostymulatora na produkcyjność pszenicy ozimej w zmianowaniu i krótkotrwałej monokulturze. Fragmenta Agronomica 30 (4): $55-64$.

Kraska P. 2010. Jakość ziarna pszenicy jarej uprawianej w monokulturze w zależności od konserwujących wariantów uprawy roli oraz międzyplonów. Biuletyn Instytutu Hodowli i Aklimatyzacji Roślin 256: 55-71.

Kwiatkowski C.A. 2012. Rola międzyplonów we współczesnym rolnictwie. Studia i Raporty Instytut Uprawy Nawożenia i Gleboznawstwa - Państwowy Instytut Badawczy 28 (2): 79-95.

Kwiatkowski C.A., Misztal-Majewska B. 2014. Wpływ międzyplonów ścierniskowych oraz sposobu uprawy roli na jakość ziarna pszenicy jarej w krótkotrwałej monokulturze. Annales Universitatis Mariae Curie-Skłodowska, Sectio E, Agricultura 69 (2): 1-10.

Małecka I., Blecharczyk A., Pudełko J. 2004. Wartość nawozowa międzyplonów ścierniskowych w różnych systemach uprawy roli. Prace Komisji Nauk Rolniczych i Komisji Nauk Leśnych 97: 41-48.

Matysiak K., Adamczewski K., Kaczmarek S. 2011. Wpływ biostymulatora Asahi SL na plonowanie i wybrane cechy ilościowe i jakościowe niektórych roślin rolniczych uprawianych w warunkach Wielkopolski. [Response of some crops cultivated in Great Poland to application of Asahi SL]. Progress in Plant Protection/Postępy w Ochronie Roślin 51 (4): 1849-1857. 
Parylak D. 1999. Wpływ wilgotności gleby i obecności międzyplonu na plon i jakość ziarna pszenżyta ozimego w monokulturze. Zeszyty Naukowe Akademii Rolniczej we Wrocławiu, Rolnictwo 74: 141-148.

Szwed-Urbaś K., Segit Z. 2004. Charakterystyka wybranych cech ilościowych u mieszańców pszenicy twardej. Annales Universitatis Mariae Curie-Skłodowska, Sectio E, Agricultura 59: 101-113.

Tendziagolska E., Parylak D. 2004. Zabiegi regeneracyjne w monokulturze pszenżyta ozimego a jakość ziarna. Pamiętnik Puławski 135: 317-324.

Wacławowicz R., Parylak D., Śniady R. 2005. Następczy wpływ nawożenia organicznego oraz mineralnego azotowego na plonowanie oraz wybrane cechy jakościowe ziarna pszenicy jarej. Pamiętnik Puławski 139: 277-288.

Weber R. 2010. Wpływ okresu stosowania systemów bezpłużnych na właściwości gleby. Postępy Nauk Rolniczych 1: 63-75.

Woźniak A. 2003. Wpływ zróżnicowanego udziału pszenicy jarej w zmianowaniu na plon i jakość ziarna. Biuletyn Instytutu Hodowli i Aklimatyzacji Roślin 228: 41-50.

Woźniak A. 2004. Wpływ przedplonu na wybrane cechy jakościowe ziarna pszenicy jarej. Pamiętnik Puławski 135: 325-330.

Woźniak A. 2005. Wpływ przedplonów na plon i jakość technologiczną ziarna pszenicy twardej (Triticum durum Desf.). Annales Universitatis Mariae Curie-Skłodowska, Sectio E, Agricultura 60: 103-112.

Woźniak A. 2006. Wpływ przedplonów na plon i jakość ziarna pszenicy ozimej. Acta Scientiarum Polonorum, Agricultura 5 (2): 99-106.

Woźniak A. 2007. Jakość ziarna pszenicy ozimej odmiany Korweta w zmianowaniach o różnym jej udziale. Acta Agrophysica 10 (1): $247-255$.

Woźniak A., Gontarz D. 2003. Wpływ przedplonów i sposobów zróżnicowanego pielęgnowania na jakość ziarna pszenicy jarej. Biuletyn Instytutu Hodowli i Aklimatyzacji Roślin 228: 33-39.

Woźniak A., Staniszewski M. 2007. Plonowanie i jakość ziarna pszenicy twardej (Triticum durum Desf.) w zależności od jej udziału w zmianowaniu. Acta Agrophysica 9 (3): 809-816. 